\title{
TEMPO POVEIKIS KETURVIEČIŲ VALČIŲ IRKLAVIMO VEIKSMINGUMUI
}

\author{
Algirdas Bingelis, Kazimieras Pukėnas, Sigita-Marija Zdanavičienė \\ Lietuvos kūno kultūros akademija, Kaunas, Lietuva
}

\begin{abstract}
Algirdas Bingelis. Docentas technikos mokslų daktaras. Informatikos ir kalbų katedros docentas. Mokslinių tyrimų kryptis — žmogaus judesių ir fiziniu gebejjimų biomechanika.
\end{abstract}

\section{SANTRAUKA}

Keturviečiu akademiniu valčiu tyrimas siejamas su ankstesniais autoriu darbais, skirtais vienviečiu ir dviviečiu valčiu irklavimo ekonomiškumo, lemiamo vertikalaus supimo, matematiniam modeliavimui. Literatūroje nesutinkama laisvojo vertikalaus supimo, kurị sukelia vertikalūs jègos impulsai i sèdynèlę kiekvieno yrio metu, poveikio analizès duomenu. Gęstantis laisvas vertikalus supimas lemia vidutini grimzlès prieaugi, kartu ir drèkinamo valties paviršiaus ploto dydi, dèl to didèja valties grimzlès prieaugis greitèjant irklavimo tempui, dideja vandens pasipriešinimo jéga.

Tyrimo tikslas - apskaičiuoti jvairiu modeliu (siauresniu - 8650 ir platesniu - 8750) keturviečiu (4x/-) valčiu irklavimo veiksmingumo rodiklius, lemiamus valties komplekso laisvojo vertikalaus supimo, ir nustatyti ju priklausomybę nuo kai kuriu valties korpuso parametru ir irkluotoju vertikalaus poveikio i sédynèle stiprumo esant skirtingam irklavimo tempui. Iš teoriniu brèžiniu nustatyti realiu akademiniu valčiu parametrai, reikalingi irklavimo veiksmingumui apskaičiuoti. Matematinio modeliavimo metodu apskaičiuotas laisvojo vertikalaus supimo sukeltas grimzlès prieaugis ir nustatytas irklavimo veiksmingumo kitimo priklausomumas nuo irklavimo tempo, valties komplekso masés ir vertikalaus supimo stiprumo.

Analizuojant gautus duomenis nustatyta, kad vertikalaus supimo koeficientas mažai priklauso nuo komplekso masès. 8750 modelio valties, kurios drèkinamo paviršiaus plotas yra didesnis nei 8650 modelio valties, vandens pasipriešinimo jèga, proporcingai drèkinamo ploto dydžiui, yra 4,5\% mažesnè. Vidutinès grimzlès prieaugio didžiausia teigiama reikšmé (blogiausios salygos) didesnè 8650 modelio valčiai. Didejjant irklavimo tempui iki 44,5 ir 47 yriu per minute (atitinkamai 8750 ir 8650 modelio valtims), grimzlès prieaugio reikšmés pasidaro lygios nuliui. Tempui toliau didejant, vidutinès grimzlès prieaugio reikšmès pasidaro neigiamos, ir tai gerina traukio sqlygas. Tolesnis tempo didinimas veiksmingesnis 8650 modelio valčiai. Duomenys apie vidutini grimzlès prieaugi traukio metu (nepriklausomai nuo tempo) sudaro prielaidas paveikiau atlikti trauki. Žinant apie vidutinès grimzlès prieaugio kitima, galima rinktis tokias tempo reikšmes, kai vidutinè grimzlè yra mažesnè. Galima teigti, kad laisvasis vertikalus supimas lemia irklavimo veiksmingumo kitima, priklausomq nuo tempo. Tai tikslinga vertinti analizuojant veiksnius, lemiančius didelio meistriškumo irkluotoju irklavimo technikq.

Raktažodžiai: vertikalus supimas, irklavimo veiksmingumas, tempas.

\section{IVADAS}

A nkstesnieji autoriu darbai susieti su vienviečiu ir dviviečiu akademinių valčių irklavimo ekonomiškumo, lemiamo vertikalaus supimo, matematiniu modeliavimu. Keturviečiu valčių tyrimas siejamas su analogišku dar vienos valčių klasès irklavimo ekonomiškumo (veiksmingumo) vertinimu.

Teoriniam akademinio irklavimo proceso matematiniam modeliavimui, biomechaninių, fiziologinių ir fizikinių veiksnių analizei skirta nema- žai darbų (Lazauskas, 1997; Abrahamsen, 2001; Baudouin, Hawkins, 2002 ir kt.). Tačiau šių darbų autoriai apsiriboja pagrindiniu biomechaninių bei fiziologinių veiksnių, lemiančių irklavimo veiksminguma, analize. Keturvietèms valtims skirtas matematinis modelis (Abrahamsen, 2001) yra per daug ribotas net esant didelei šios klasès valčiu įvairovei. Nagrinejjant valčiu įvairovę nepateiktas keturvietès pavyzdys (Lazauskas, 1998). Modeliuojant irklavimo procesą sunku ivertinti visus veiksnius, todèl 
atmetami mažiau turintys įtakos. Vertinant pagrindines veikiančias jègas atmetamos vertikaliai veikiančios jëgos teigiant, kad jos gali turèti nedideli poveiki. Tai poveikiai, susiję su vertikaliais valties judesiais. Tyrejai (Baudouin, Hawkins, 2002) teigia, kad vertikalus supimas irklavimo veiksmingumui didelio poveikio neturi, nes priverstinis vertikalus supimas, susijęs su irklavimo tempu, nekeičia vidutinès grimzlès dydžio.

Tyrëjas V. Kleshnev (1999), apdorodamas irkluotojų testavimo rezultatus, nustate, kad irklavimo veiksmingumas mažeja didèjant tempui. Irklavimo (valties) veiksmingumas nusakomas traukio galingumo ir vandens pasipriešinimo galingumo santykiu. Didejant tempui, vandens pasipriešinimas dideja. Tikro teorinio paaiškinimo nepateikiama. V. Kleshnev (2006) kreipia ypatingą dèmesi i didelio meistriškumo irkluotojų, aukšto rango varžybų prizininkų, rezultatų skirtumus, todèl nagrinèja veiksnius, turinčius vienetų ar procentų daliu poveiki. Veiksmingumo mažejimą jis taip pat aiškina bangu pasipriešinimo kitimu, esant kiliniam valties supimui tempo dažniui.

Literatūroje nesutinkama užuominų apie laisvojo vertikalaus supimo egzistavimą. Išorinis supimo vaizdas nublanksta prieš ispūdingus irkluotoju judesius, todèl pastebèti ji sunku. Laisvojo vertikalaus supimo reiškini A. Bingelis ir J. Daniševičius (1994) pastebėjo nagrinèdami kitu autorių užregistruotą priverstini kilini valčių supimą. Jị sukelia valtị veikiantys vertikalūs jègos impulsai i sèdynèlę kiekvieno yrio metu. Gęstantis laisvasis vertikalus supimas lemia vidutini grimzlès prieaugi, tuo pačiu drèkinamo valties paviršiaus ploto dydị. Didejjant tempui, grimzlès prieaugis didejja, todèl didejja vandens pasipriešinimo jèga.

Rungtyniaujant didelio meistriškumo lygiaverčiams varžovams, pergalę gali lemti sekundès dalys, todèl tikslinga îvertinti visus irklavimo procesą lemiančius veiksnius, ne tik pagrindinius.
Tyrimo tikslas - apskaičiuoti akademinių keturviečių ( $4 \mathrm{x} /-)$ įvairių modelių valčių irklavimo veiksmingumo rodiklius, lemiamus valties komplekso laisvojo vertikalaus supimo, nustatyti veiksmingumo rodikliu priklausomybę nuo kai kurių valties korpuso parametrų ir irkluotojų vertikalaus poveikio i sèdynèlę stiprumo, palyginti tarpusavyje valtis ir ju galimybes, pateikti rekomendacijas irklavimo veiksmingumui didinti.

Tyrimo metu sprendžiami uždaviniai:

- Iš teorinių brèžinių nustatyti realių akademinių keturviečiu valčiu parametrus, reikalingus irklavimo veiksmingumui apskaičiuoti.

- Matematinio modeliavimo metodu pagal valčiu kompleksu ir irkluotojų duomenis apskaičiuoti laisvojo vertikalaus supimo sukeltą grimzlès prieaugi.

- Iš vandens pasipriešinimo prieaugio rodikliu nustatyti irklavimo veiksmingumo kitimo priklausomumą nuo tempo, valties komplekso masès ir vertikalaus poveikio stiprumo.

- Nustatyti sąlygas, mažinančias rankų nuovargi.

\section{TYRIMO METODAI IR ORGANIZAVIMAS}

Irklavimo veiksmingumo kitimo priklausomumas nuo tempo $S F\left(S F=60 / T_{Z}\right)$ grindžiamas veikiančios sèdynèlę tam tikrą laikotarpi $t_{S}$ vertikalios krypties jègos $F_{S}(t)$ impulso $I_{S}$ sukelto laisvojo gęstančio valties vertikalaus supimo ivertinimu. Didžiausios jègos $F_{S \max }$ vertikalus poveikis í sėdynèlę vèluoja laiko trukme $t_{V}$ traukio jègos $F_{D}(t)$ trukmès $t_{D}$ impulso pradžios atžvilgiu (1 pav.).

Toks supimas sukelia grimzlès $T \zeta(t)$ ir valties drèkinamo paviršiaus ploto $S$ prieaugi $\Delta S$. Tai didina vandens pasipriešinimo jègą.
1 pav. Traukio jègos $\boldsymbol{F}_{D}(t)$ ir vertikalaus poveikio ị sèdynèlę jègos $F_{S}(t)$ sąsajos

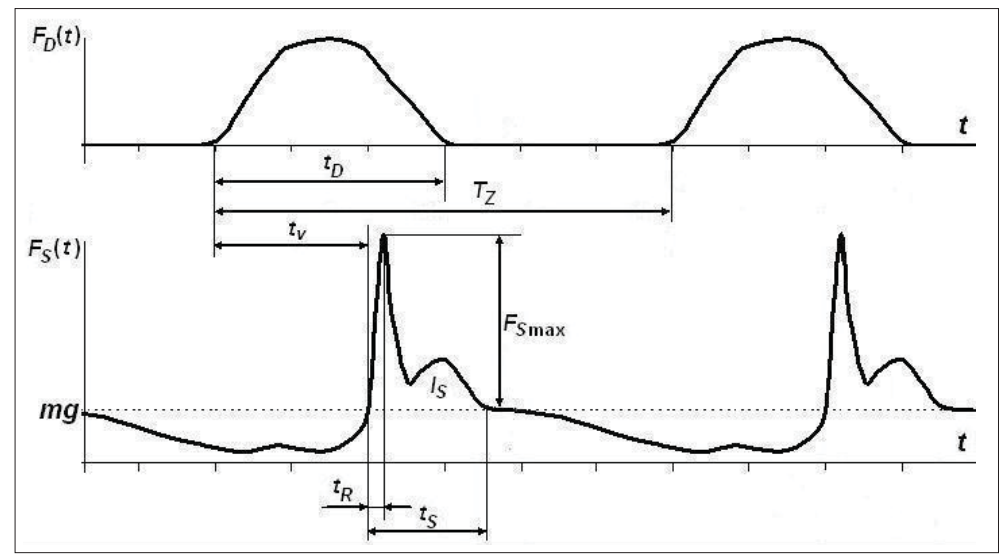




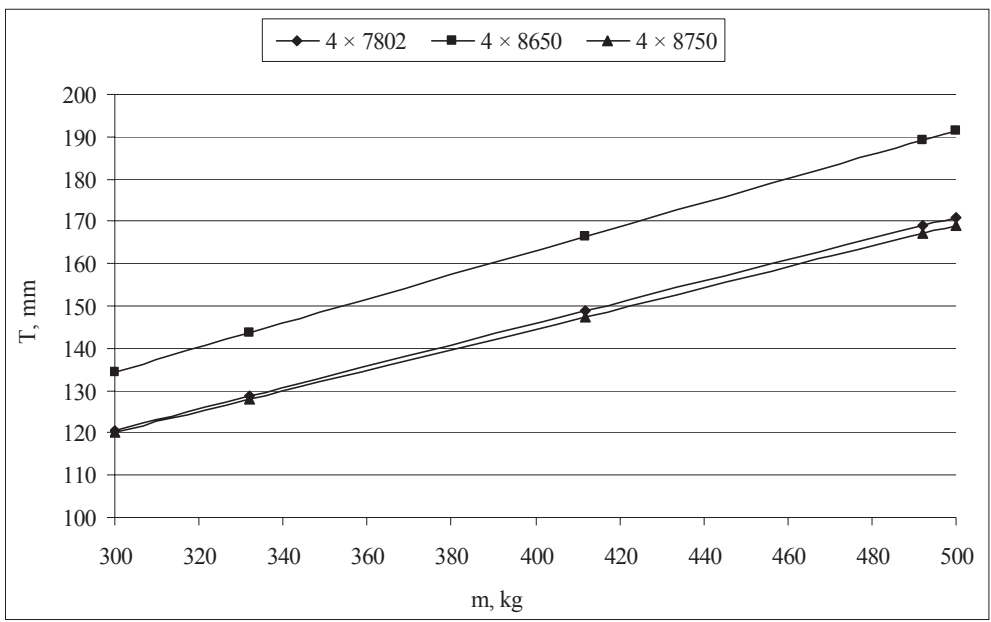

2 pav. Valčių grimzlès $\boldsymbol{T}$ priklausomybè nuo valties komplekso masès $\boldsymbol{m}$

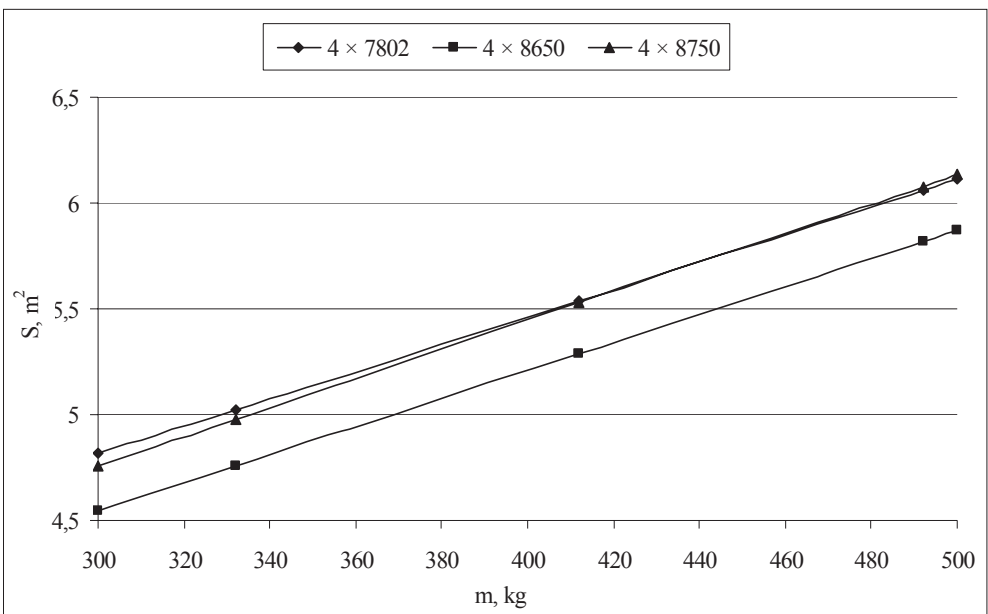

3 pav. Valčių drèkinamo paviršiaus ploto $S$ priklausomybė nuo valties komplekso masès $m$

Sudètinga vertikalaus poveikio jègos impulso forma apskaičiuojant aproksimuojama laužte pagal išraiška:

$$
F_{S}(t)=\sum_{j=0}^{k} a_{j}\left(t-\tau_{j}\right) u\left(t-\tau_{j}\right),
$$

čia $k$ - laužtès atkarpų skaičius;

$j$ - laužtès lūžio taško laiko momento eilès numeris;

$\tau_{j}$ - laiko $t$ reikšmè $j$-ame laužtès taške;

$a_{j}$ - koeficientas $\left[a_{j}=\left(F_{S j+1}-F_{S j}\right) /\left(\tau_{j+1}-\tau_{j}\right)-\left(F_{S j}-F_{S j-1}\right) /\right.$ $\left.\left(\tau_{j}-\tau_{j-1}\right)\right]$

$F_{S j}$ - jègos $F_{S}(t)$ reikšmès laiko momentais $\tau_{j}$, ir $u\left(t-\tau_{j}\right)$ vienetinè funkcija $\left(u=0\right.$, kai $t<\tau_{j} ; u=1$, kai $\left.t \geq \tau_{j}\right)$.

Grimzlès prieaugio $\zeta(t)$ matematine išraiška, gaunama išsprendus antros eilès diferencinę lygti (Bingelis ir Daniševičius, 1994), aprašančią valties laisvaji vertikalų supimą, lemiamą traukio pabaigoje vertikalios krypties jejgos $F_{S}(t)$ pagal vienkartinio impulso poveikio (1) formulę.

Dydžio $\zeta(t)$ reikšmé gaunama pagal visoms valčių klasėms tinkančią (2) formulę:

$$
\zeta(t)=\frac{1}{m} \sum_{j=0}^{k} a_{j} u\left(t-\tau_{j}\right)\left\langle\frac{t-\tau_{j}}{\eta^{2}}-\frac{2 v}{\eta^{4}}\left\{1-\frac{\eta^{2}}{2 v \omega} \mathrm{e}^{-v\left(t-\tau_{j}\right)} \cos \left[\omega\left(t-\tau_{j}\right)+\operatorname{arctg} \frac{\eta^{2}-2 v^{2}}{2 v \omega}\right]\right\}\right),
$$

čia $m$ - valties komplekso (valties, irklų ir ekipažo) masè; $\eta$ - laisvojo supimo kampinis dažnis $(\eta=2 \pi /[2,5 \sqrt{T}])$ (Семенов-Тян-Шанский и др., 1969);

$\omega-$ supimo kampinis dažnis įvertinant slopimą $\left(\omega^{2}=\eta^{2}\right.$ $\left.-v^{2}\right)$

$j, k, \tau_{j}, \alpha_{j}$ - jègą $F_{s}(t)(1)$ formulèje aprašomi parametrai.

Valties komplekso nusistovèjęs po penkto yrio laisvojo vertikalaus supimo procesas aprašomas matematiniu reiškiniu (Bingelis, Daniševičius, 1994):

$\zeta_{\Sigma}(t)=\sum_{i=1}^{5} u\left[t-(i-1) T_{Z}\right] \zeta\left[t-(i-1) T_{Z}\right]$

čia $\zeta_{\Sigma}(t)-$ suminis grimzlès prieaugis;

$i$ - yrio eilès numeris;

$u\left(t-(i-1) T_{\mathrm{z}}\right)-$ vienetinè funkcija $\left(u=0\right.$, kai $t<(i-1) T_{\mathrm{z}}$ ir $u=1$, kai $\left.t \geq(i-1) T_{\mathrm{z}}\right)$;

$\zeta\left(t-(i-1) T_{\mathrm{z}}\right)$ - grimzlès prieaugio kitimas veikiant vienkartiniam jègos $F_{S}(t)$ impulsui $I_{S}$ nuo laiko momento $t>$ $(i-1) T_{\mathrm{z}}$. 
4 pav. Valčių vertikalaus supimo slopimo koeficiento $v$ priklausomybè nuo valties komplekso masès $m$
5 pav. Valčių drėkinamo paviršiaus ploto $S$ priklausomybẻ nuo grimzlès $T$
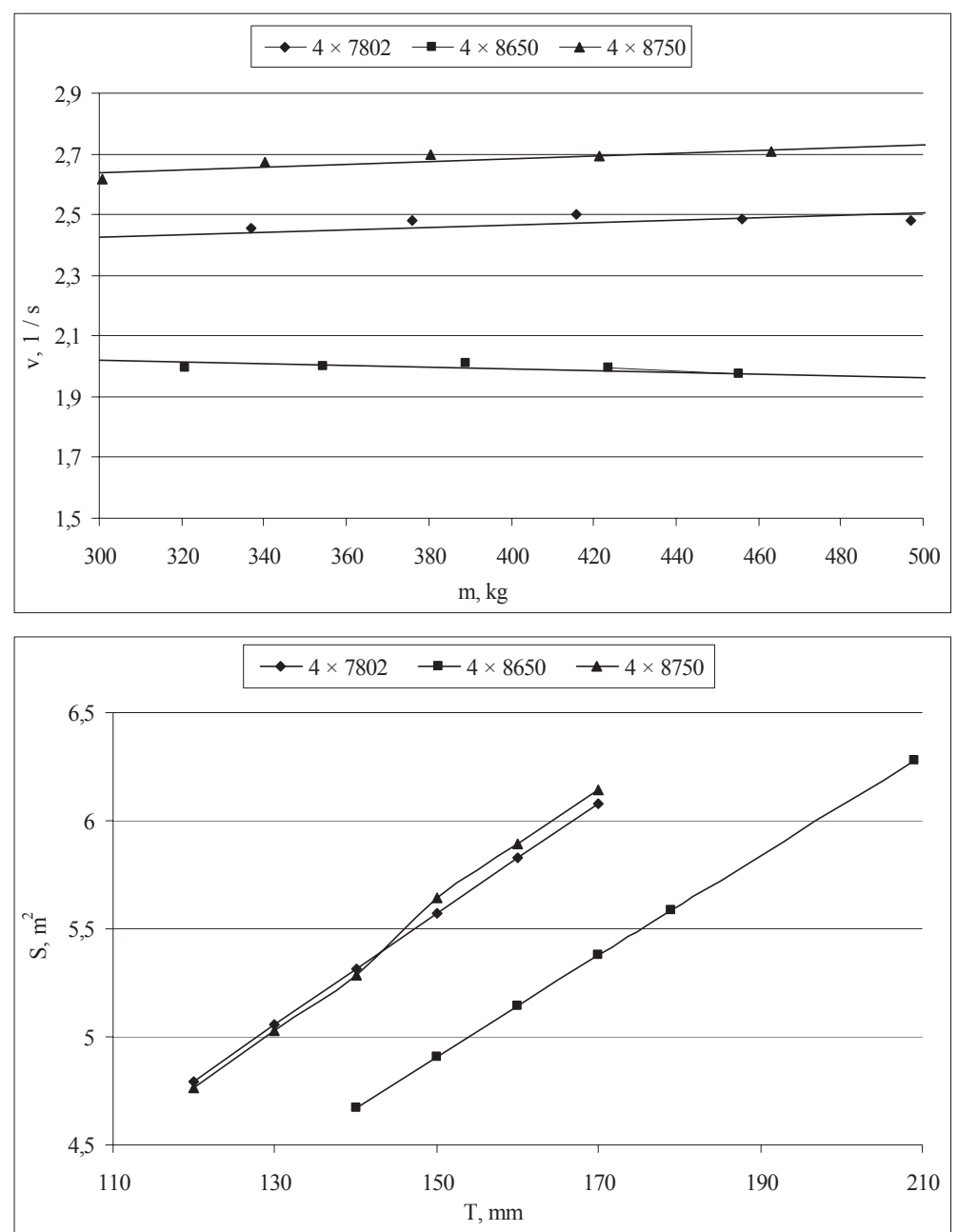

Vidutinis grimzlès prieaugis yrio metu:

$$
\bar{\zeta}_{Z}=\frac{1}{T_{Z}} \times \int_{0}^{T_{Z}} \zeta_{\Sigma}(t) \mathrm{d} t .
$$

Vidutinis grimzlès prieaugis traukio metu:

$$
\bar{\zeta}_{D}=\frac{1}{t_{D}} \times \int_{0}^{t_{D}} \zeta_{\Sigma}(t) \mathrm{d} t .
$$

Vidutinis grimzlès prieaugis užkèlio metu:

$$
\bar{\zeta}_{D Z}=\frac{1}{T_{Z}-t_{D}} \times \int_{t_{D}}^{T_{Z}} \zeta_{\Sigma}(t) \mathrm{d} t .
$$

Valties drėkinamo paviršiaus ploto $S$ prieaugis $\Delta S$, atsiradęs dèl grimzlès prieaugio $\bar{\zeta}_{Z}$, nusakomas išraiška:

$$
\Delta S=B_{S T} \cdot \bar{\zeta}_{Z}
$$

čia $B_{S T}$ - valties drèkinamo paviršiaus ploto $S$ priklausomybès nuo grimzlès $T$ proporcingumo koeficientas.

Vandens pasipriešinimo jèga proporcinga drèkinamo paviršiaus plotui. Todèl laisvojo vertikalaus supimo poveikio kitimą i̇vairioms tempo
$S F$ reikšmėms galima išreikšti veiksmingumo koeficientu:

$$
E K_{S}(S F)=S /[S+\Delta S(S F)]
$$

Esant vienodam vandens pasipriešinimui, vidutinio valties greičio $v_{\zeta}$ (kai yra vertikalus supimas) ir $v_{0}$ (kai nėra vertikalaus supimo) santykis arba taip išreikštas veiksmingumo koeficientas:

$$
E K_{V}(S F)=v_{\varsigma} / v_{0}=\sqrt{S /[S+\Delta S(S F)]}
$$

apibūdina vertikalaus poveikio į sèdynèlę poveiki valties komplekso vidutiniam greičiui.

Tyrimams panaudoti Eksperimentinio konstravimo centro „Latvijas laivas“ projektuotų ir gamintų keturviečių akademinių valčių (modeliai 7802, 8650 ir 8750, analogiški firmos Empacher modeliams) teoriniai brèžiniai. Pagal teorinius brèžinius trapecijų metodu (Čerka, 1997) nustatytos valčių rodikliu priklausomybès, siejančios apkrovą — valties komplekso (valties, irklų ekipažo) masę $m$, valties grimzlę $T$, drékinamo paviršiaus plotą $S$ ir pagal Salkajevo grafikus vertikalaus supimo slopimo ko- 


\begin{tabular}{|c|c|c|c|c|}
\hline \multicolumn{2}{|c|}{ Regresijos lygties } & \multicolumn{2}{|c|}{ Valtis } & \multirow{10}{*}{$\begin{array}{l}1 \text { lentelè. }(\mathbf{1 0}),(11),(12) \text { ir }(\mathbf{1 3}) \\
\text { regresijos lygčių koeficientu } \\
\text { reikšmés }\end{array}$} \\
\hline Numeris & Koeficientas & 8650 & 8750 & \\
\hline \multirow{2}{*}{10} & $A_{T m}$ & 49,144 & 46,998 & \\
\hline & $\mathrm{B}_{\mathrm{Tm}}$ & 0,2845 & 0,2439 & \\
\hline \multirow{2}{*}{11} & $A_{S m}$ & 2,553 & 2,6962 & \\
\hline & $\mathrm{B}_{\mathrm{Sm}}$ & 0,006641 & 0,006876 & \\
\hline \multirow{2}{*}{12} & $A_{v m}$ & 2,1066 & 2,5059 & \\
\hline & $\mathrm{B}_{\mathrm{vm}}$ & $-0,000291$ & 0,000446 & \\
\hline \multirow{2}{*}{13} & $A_{S T}$ & 1,4057 & 1,3703 & \\
\hline & $\mathrm{B}_{\mathrm{ST}}$ & 0,023342 & 0,02802 & \\
\hline
\end{tabular}

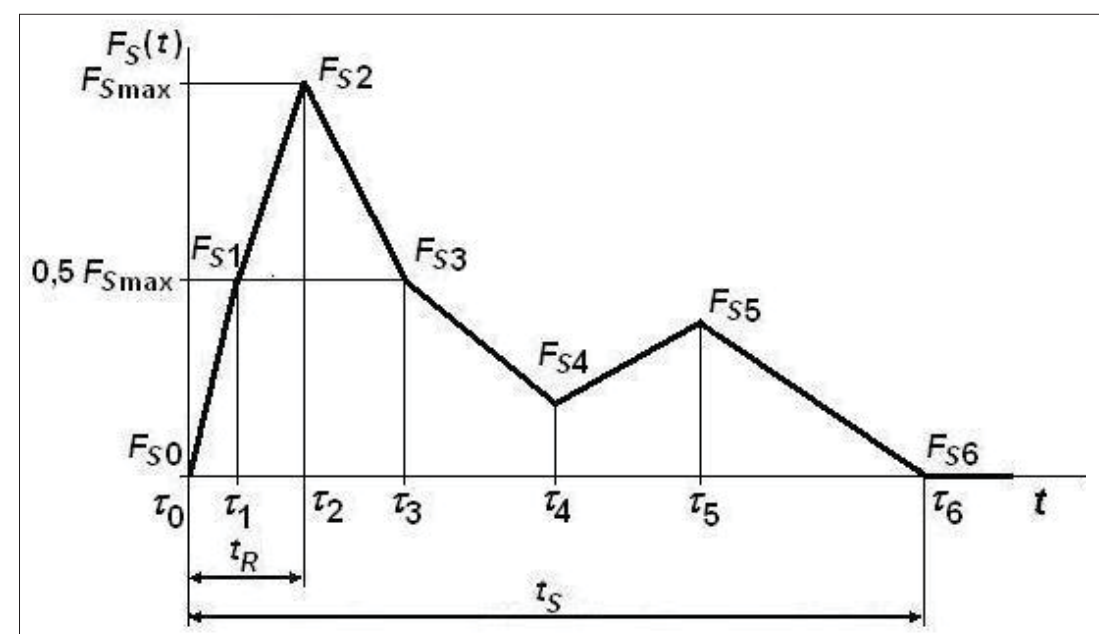

6 pav. Skaičiavimams naudojamas jègos $\boldsymbol{F}_{S}$ (t) pavidalas

eficientus $v$ (Семенов-Тян-Шанский и др., 1969). Valčių rodikliai apskaičiuojami valties komplekso masès $m$ ribose nuo $332 \mathrm{iki} 492 \mathrm{~kg}$. I masę $m$ įeina keturių irkluotojų vienodos masès $m_{r}$ ribose nuo 65 iki $105 \mathrm{~kg}$. Valčių rodiklių priklausomybè grafiškai pavaizduota 2, 3, 4 ir 5 pav.

Valčių 7802 ir 8750 duomenys panašūs. Valties 8650 duomenys skiriasi nuo minètų valčių duomenų, nes ji apie 10 procentu siauresnè. Todèl esant vienodai apkrovai jos grimzlè didesnè. Tolesniam nagrinèjimui paliekame tik skirtingas valtis 8650 ir 8750. Remiantis tiesine regresine analize, šių valčių grimzlès $T$ (determinacijos koef. $\left.r^{2}=0,999\right)$, drèkinamojo paviršiaus ploto $S$ (determinacijos koef. $\left.r^{2}>0,997\right)$, vertikalaus supimo slopimo koeficientu $v$ (determinacijos koef. $r^{2}>0,8$ ) priklausomybė nuo valčių kompleksų masès $m$ ir drèkinamo paviršiaus ploto $S$ (determinacijos koef. $r^{2}>0,997$ ) priklausomumas nuo grimzlès $T$, aprašoma (10), (11), (12) ir (13) regresijos lygtimis, kurių koeficientu reikšmès pateiktos 1 lenteleje.

$$
\begin{aligned}
& \mathrm{T}=\mathrm{A}_{\mathrm{Tm}}+\mathrm{B}_{\mathrm{Tm}} \mathrm{m} \\
& \mathrm{S}=\mathrm{A}_{\mathrm{Sm}}+\mathrm{B}_{\mathrm{Sm}} \mathrm{m} \\
& \mathrm{V}=\mathrm{A}_{\mathrm{vm}}+\mathrm{B}_{\mathrm{vm}} \mathrm{m} \\
& \mathrm{S}=\mathrm{A}_{\mathrm{ST}}+\mathrm{B}_{\mathrm{ST}} \mathrm{T}
\end{aligned}
$$

Skaičiuojant yrio $T_{Z}$, traukio $t_{D}$ ir užkèlio $t_{D Z}$ laikotarpiu grimzlès prieaugius, esant skirtingam tempui, ivertinama traukio $t_{D}$, impulso $I_{S}$ vèlinimo $t_{V}$, vertikalios jègos $F_{S}(t)$ didžiausios reikšmès $F_{S \max }$ ir jègos veikimo trukmès $t_{\mathrm{S}}$ priklausomybè nuo tempo $S F$. Tuo tikslu naudojami 16-60 1/ min tempo ribose testuotuc 48 irkluotojų 84 rezultatų kompleksai. Jų pagrindu gautos jègų ir laiko parametru priklausomybès nuo tempo tiesinès regresijos lygčių pavidalu:

$$
\begin{array}{ll}
t_{D}=-0,0083 \mathrm{SF}+1,0173 & \text { su } \mathrm{r}^{2}=0,2762, \\
\mathrm{t}_{\mathrm{V}}=-0,0055 \mathrm{SF}+0,7196 & \text { su } \mathrm{r}^{2}=0,2016, \\
\mathrm{t}_{\mathrm{S}}=-0,008 \mathrm{SF}+0,7766 & \text { su } \mathrm{r}^{2}=0,2074, \\
\mathrm{~F}_{\text {Smax }}=19,79 \mathrm{SF}+257 & \text { su } \mathrm{r}^{2}=0,1443 .
\end{array}
$$

Traukio jëgos $F_{D}(t)$ impulsas vaizduojamas sinusoidès teigiamu pusperiodžiu: amplitudè $F_{D \max }$ atitinka laiko momentą $0,5 t_{D}$. Irklo kampas traukio metu kinta nuo 30 iki 120 laipsnių nepriklausomai nuo tempo.

Skaičiuojant realius grimzlès prieaugio dydžius pagal (2) formulę naudojamas jègos $F_{S}(t)$ pavidalas, pavaizduotas 6 pav. Todèl (1) formulèje $k=6$. Atskirų laužtės taškų laiko ir amplitudès pa- 
2 lentelè. Jègos $\boldsymbol{F}_{S}(\boldsymbol{t})$ laiko ir amplitudès santykis

\begin{tabular}{|l|c|c|c|c|c|c|c|}
\hline \multicolumn{1}{|c|}{ Laiko momentai } & $\tau_{0}$ & $\tau_{1}$ & $\tau_{2}$ & $\tau_{3}$ & $\tau_{4}$ & $\tau_{5}$ & $\tau_{6}$ \\
\hline 7 pav. - laiko duomenys, $\mathrm{s}$ & 0 & 0,012 & 0,036 & 0,066 & 0,132 & 0,208 & 0,34 \\
\hline Atkarpos trukmé, s & 0 & $0,035 t_{S}$ & $0,106 t_{S}$ & $0,194 t_{S}$ & $0,388 t_{S}$ & $0,612 t_{S}$ & $1 t_{S}$ \\
\hline 7 pav. - amplitudé, $\mathrm{N}$ & 0 & 865 & 1730 & 865 & 156 & 393 & 0 \\
\hline Amplitudés santykis & 0 & $0,5 F_{\text {Smax }}$ & $F_{\text {Smax }}$ & $0,5 F_{S \max }$ & $0,09 F_{\text {Smax }}$ & $0,227 F_{\text {Smax }}$ & 0 \\
\hline
\end{tabular}

7 pav. Irkluotojo jègos $F_{S}(t)$ pavidalas (̌̌r. 2 lent.)

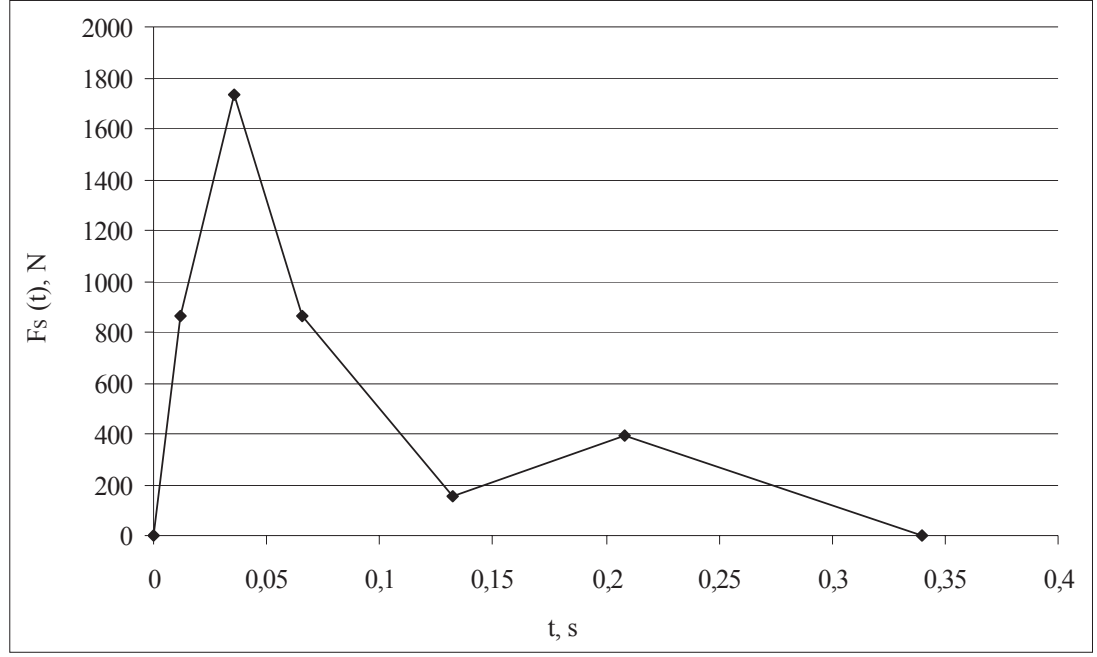

rametrai nurodyti 2 lentelëje laiko ir amplitudžiu santykių pavidalu. Dydžiai gauti remiantis apie 100 irkluotoju jègos $F_{S}(t)$ matavimo ir jų vidurkinimo būdu. Kadangi vidurkinis pavidalas pasirodè artimas žinomo olimpinio prizininko jègos $F_{S}(t)$ pavidalui, jo duomenys (7 pav.) priimti ,standartu" ir panaudoti skaičiuojant. Laiko ir amplitudès santykiai išlaikomi pastovūs pagal 2 lentelę kintant patiems dydžiams $t_{\mathrm{S}}$ ir $F_{\text {Smax }}$ pagal (16) ir (17) formules priklausomai nuo tempo.

Didinant ar mažinant vertikalaus poveikio amplitudę proporcingai kinta grimzlès prieaugio dydis pagal (2) formulę.

\section{REZULTATAI}

Irklavimo tempo ribose nuo $21 \mathrm{iki} 501 / \mathrm{min}$ apskaičiuoti yrio $T_{Z}$, traukio $t_{D}$ ir užkèlio $t_{D Z}$ laikotarpių vidutinès grimzlès prieaugių rezultatai pateikti 8, 9 ir 10 pav. Rezultatai vaizduojami valtis 8650 ir 8750 apibūdinančiomis trijų masès dydžiu (332, 412 ir $492 \mathrm{~kg})$ kreiviu šeimomis.

Vidutinis grimzlès prieaugis yrio metu gali būti aprašytas tiesinès regresijos $\left(r^{2}=0,999\right)$ lygtimis:

$$
\begin{aligned}
& \overline{\bar{\zeta}_{Z}}=0,2524 \mathrm{SF}-4,2251 \quad(8650 \quad 332 \mathrm{~kg}) \\
& \underline{\zeta_{Z}}=0,2357 \mathrm{SF}-3,9473 \quad(8650 \quad 412 \mathrm{~kg}) \\
& \zeta_{Z}=0,2244 \mathrm{SF}-3,7569 \quad(8650 \quad 492 \mathrm{~kg})
\end{aligned}
$$

$$
\begin{aligned}
& \bar{\zeta}_{Z}=0,225 \mathrm{SF}-3,7673 \quad(8750 \quad 332 \mathrm{~kg}) \\
& \zeta_{Z}=0,209 \mathrm{SF}-3,5014 \quad(8750 \quad 412 \mathrm{~kg}) \\
& \zeta_{Z}=0,1982 \mathrm{SF}-3,3189 \quad(8750 \quad 492 \mathrm{~kg})
\end{aligned}
$$

Vertikalaus poveikio stiprumas iqvertintas apskaičiuojant vidutinio grimzlès prieaugio dydi yrio metu keičiant jègą $F_{S}(t)$ ribose nuo 50 iki $150 \%$ (11 pav.). Panašus proporcingumas gaunamas apskaičiuojant vidutinius grimzlès prieaugius traukio ir užkèlio metu. Jų priklausomybių pavidalas panašus į pavaizduotus 9 ir 10 pav.

\section{REZULTATŲ APTARIMAS}

Siauresnès valties 8650 statiné grimzlè ( 2 pav.) priklausomai nuo valties komplekso masès (332; 412 ir $492 \mathrm{~kg}$ ) yra 143,$6 ; 166,4$ ir $189,1 \mathrm{~mm}$ bei 10,$9 ; 11,4$ ir $11,7 \%$ didesnè negu platesnès valties 8750 (128; 147,5 ir $167 \mathrm{~mm})$. Todèl laisvojo vertikalaus supimo dažnis atitinkamai valties 8650 $(6,63 ; 6,16$ ir $5,78 \mathrm{~Hz})$ yra mažesnis negu valties $8750(7,03 ; 6,54$ ir $6,15 \mathrm{~Hz})$. Slopimo koeficientas mažai priklauso nuo masès (4 pav.), tačiau siauresnès valties 8650 vidutiniškai yra 1,9871 / s, o valties 8750 vidutiniškai yra 2,69 1/ s (skiriasi 35,2\%). Todèl valties 8750 supimas slopsta greičiau.

Siauresnès valties 8650 drèkinamo paviršiaus plotas $\left(4,758 ; 5,289\right.$ ir $\left.5,82 \mathrm{~m}^{2}\right)$ priklausomai nuo masès yra mažesnis negu valties $8750(4,979$; 

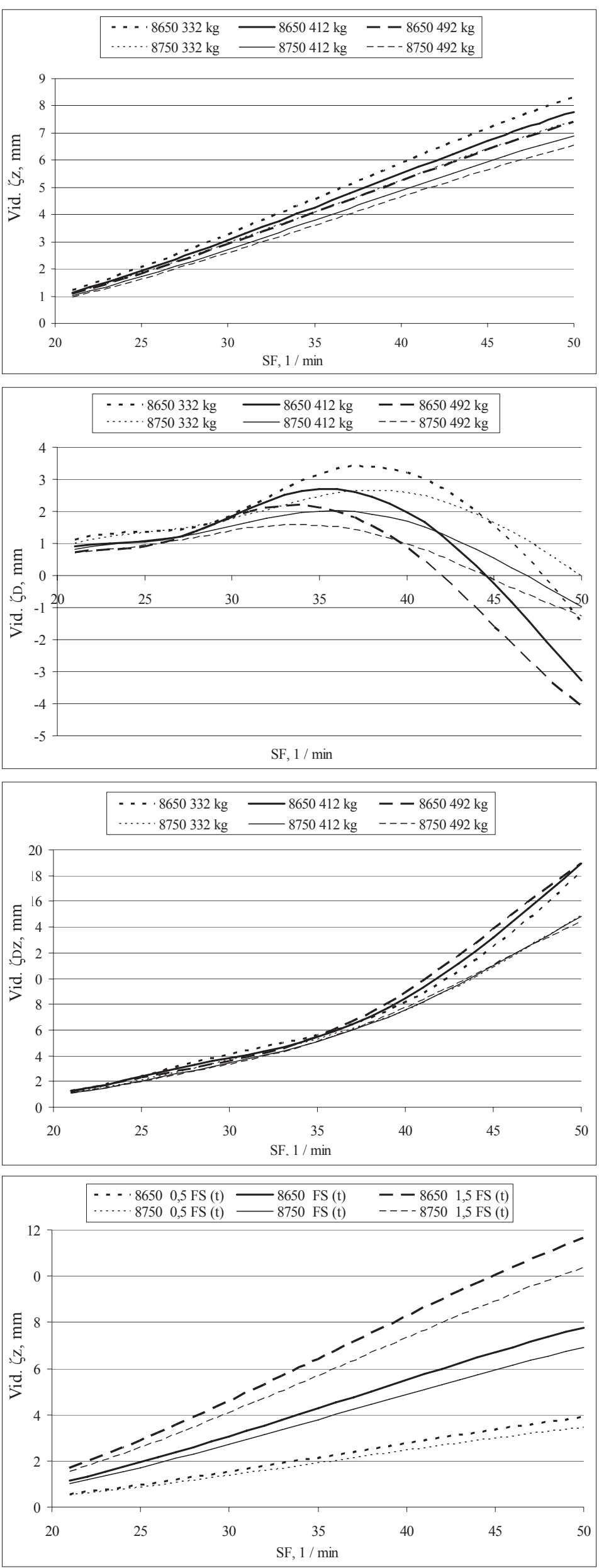

8 pav. Vidutinio grimzlès prieaugio yrio metu priklausomybė nuo valties komplekso masės ir irklavimo tempo

9 pav. Vidutinio grimzlès prieaugio traukio metu priklausomybė nuo valties komplekso masės ir irklavimo tempo

10 pav. Vidutinio grimzlès prieaugio užkèlio metu priklausomybė nuo valties komplekso masės ir irklavimo tempo

11 pav. Vidutinio grimzlès prieaugio yrio metu priklausomybė nuo vertikalaus poveikio stiprumo ribose $0,5-1,5 F_{S}(t)$ 
12 pav. Veiksmingumo koeficiento, lemiamo vidutinio grimzlès prieaugio kitimu yrio metu, priklausomybė nuo tempo

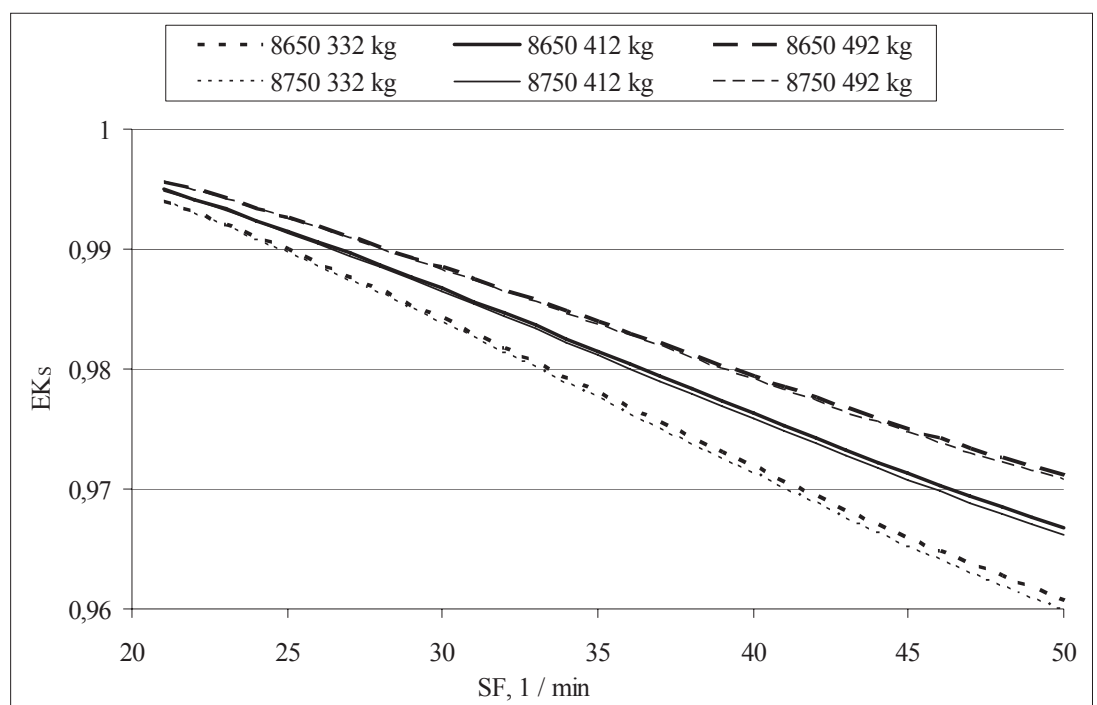

13 pav. Veiksmingumo koeficiento, lemiamo vidutinio greičio kitimo, priklausomybè nuo tempo
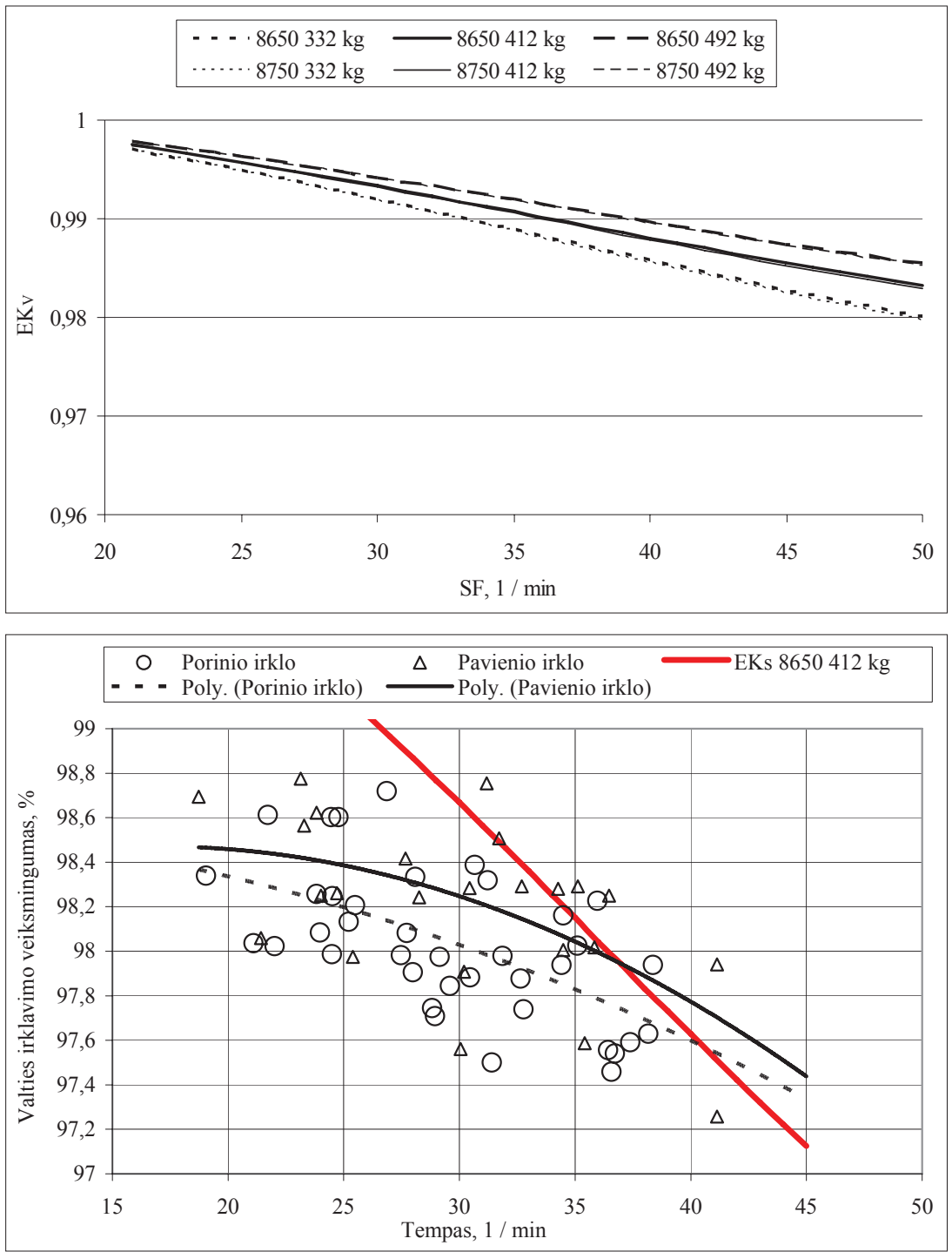

14 pav. Valties irklavimo veiksmingumo priklausomybè nuo tempo
5,529 ir $6,079 \mathrm{~m}^{2}$ ). Todèl valties 8650 vandens pasipriešinimo jèga, proporcingai drèkinamo ploto dydžiui, mažesnè $4,5 \%$.

Vidutinès grimzlès prieaugio traukio metu reikšmé priklauso nuo valties parametru, valties komplekso masès ir irklavimo tempo. Teigiamas vidutinès grimzlès prieaugio ( 9 pav.) didžiausia reikšmė (blogiausios sąlygos) didesnè siauresnei valčiai 8650 apie $0,7 \mathrm{~mm}$ negu platesnei 8750 , nors šiuos dydžius atitinkančios tempo reikšmès mažai skiriasi (35,7 ir $361 / \mathrm{min}$ ). Didejjant tempui (nuo tempo su didžiausia grimzlès prieaugio reikšme), 
grimzlès prieaugis mažèja. Valties 8650 ir valties 8750 vidutinès grimzlès prieaugio reikšmès lygios nuliui, esant tempui 44,5 ir 471 / min atitinkamai. Toliau didejjant tempui, vidutinès grimzlès prieaugiu reikšmès gauna neigiamą ženklą, gerindamos traukio sąlygas. Tolesnis tempo didinimas veiksmingesnis siauresnei valčiai. Toks dèl laisvojo vertikalaus supimo kintantis vidutinis grimzlès prieaugis traukio metu neproporcingai tempo dydžiui gali būti panaudotas paveikiau atlikti trauki. Tyrejjai Y. Liu ir kt. (1996), tirdami irkluotojų nuovargi, nustate, kad rankos greičiau nuvargsta negu kojos. Todèl rekomenduoja tausoti rankas. Daugiausia rankos pavargsta traukio metu. Todèl žinant apie neproporcingą tempui vidutinès grimzlès prieaugio kitimą galima rinktis tokias tempo reikšmes, kai vidutinè grimzlè yra mažesnè ( 9 pav.).

Vidutinis grimzlès prieaugis užkèlio metu priklausomai nuo tempo dideja (10 pav.). Didejimas stipreja tempui viršijus $351 /$ min reikšmę. Tačiau šioje fazejje rankos praktiškai nedalyvauja.

Didinant vertikalų poveikị i sėdynėlę vidutinis grimzlès prieaugis proporcingai dideja (11 pav.), tuo mažindamas irklavimo veiksmingumą. Toks poveikis skirtumo tarp irklavimo veiksmingumo beveik nekeičia. Keičiant vertikalios jègos dydị ribose $0,5-1,5 F_{S}(t)$ ir tempa ribose $30-501 / \mathrm{min}$ veiksmingumo koeficientas $E K_{S}$ dèl vandens pasipriešinimo kinta $0,5-1,5 \%$, o veiksmingumo koeficientas $E K_{V}$ dèl greičio beveik du kartus mažesnis negu $E K_{S}$.

Kintant valties komplekso masei $\pm 80 \mathrm{~kg}$ atžvilgiu vidutinès masės $412 \mathrm{~kg}$ tempo ribose 30-50 1/ min veiksmingumo koeficientas $E K_{S}$ dèl vandens pasipriešinimo kinta $0,18-0,65 \%$, o veiksmingumo koeficientas $E K_{V}$ dèl greičio beveik du kartus mažesnis negu $E K_{S}$.

Mūsų teoriškai apskaičiuoto pagal (8) formulę valties $8650(412 \mathrm{~kg})$ veiksmingumo koeficiento sutapimas patenkinamas (14 pav.), lyginant su praktinių statistikos duomenų apdorojimo rezultatais (Kleshnev, 1999). Todèl galima teigti, kad laisvojo vertikalaus supimo egzistavimas gali būti irklavimo veiksmingumo kitimo nuo tempo priežastimi. Tai tikslinga vertinti analizuojant veiksnius, lemiančius didelio meistriškumo irkluotojų irklavimo techniką.

\section{IŠVADOS}

1. Siauresnès valties drèkinamas paviršiaus plotas mažesnis, todèl jos irklavimo veiksmingumas didesnis dèl mažesnio vandens pasipriešinimo.

2. Laisvojo vertikalaus supimo požiūriu mažesnè valties komplekso masė blogina irklavimo veiksmingumą.

3. Stiprinant vertikalu poveikị i sėdynėlę irklavimo veiksmingumas proporcingai mažèja.

4. Irklavimo veiksmingumas mažèja $0,1 \% /(1 / \mathrm{min})$, jei vidutinè irkluotojo masè $85 \mathrm{~kg}$.

5. Laisvojo vertikalaus supimo teorija pagristas irklavimo veiksmingumo kitimas nuo tempo praktiškai atitinka kitų tyrejjų eksperimentinius duomenis.

6. Rekomendacija tausoti rankas irklavimo metu gali būti siejama su irklavimo tempo parinkimu, žinant vidutinio grimzlès prieaugio mažèjimo galimybes traukio metu.

\section{LITERATŪRA}

Abrahamsen, A. (2001). Rowing Model for a Four. May 18. Prieiga internetu: http://online.redwoods.cc.ca.us/instruct/darnold/deproj/Sp01/A1/Rowingpaper_s.pdf

Baudouin, A., Hawkins, D. (2002). A biomechanical review of factors affecting rowing performance. British Journal of Sports Medicine, 36, 396- 402.

Bingelis, A., Daniševičius, J. (1994). Teorinis akademinio irklavimo tempo tyrimas. Sporto mokslo žinios, 1 , $19-30$.

Čerka, J. (1997). Laivo teorija. Klaipeda: KU.

Kleshnev, V. (1999). Propulsive efficiency of rowing. In Proceedings of the XVII International Symposium on Biomechanics in Sports (pp. 224-228). Western Australia, Perth: Cowan University. Prieiga internetu: ruina.tam. cornell.edu/research/topics/locomotion and robotics/papers/oar_efficiency.pdf

Kleshnev, V. (2006). Rowing Biomechanics Newsletter. Volume 6 No 67 October. Prieiga internetu: http://www.
biorow.com/RBN en 2006 files/2006RowBiomNews 10 . pdf

Lazauskas, L. (1997). A Performance Prediction Model for Rowing Races. Department of Applied Mathematics, University of Adelaide, Technical Report: L9702. Prieiga per internetą: http://www.maths.adelaide.edu.au/Applied/ llazausk/hydro/rowing/stroke/stroke.htm.

Lazauskas, L. (1998). Rowing Shell Drag Comparisons. Department of Applied Mathematics, University of Adelaide, Technical Report: L9701. Prieiga internetu: http:// www.cyberiad.net/library/rowing/real/realrow.htm

Liu, Y., Lormes, W., Opitz-Gress, A. et al. (1996). Are the arm muscles prior to the leg muscles to be fatigued in rowing? Medicine and Science in Exercise and Sports, 28 (5), Supplement abstract 306.

Семенов-Тян-Шанский, В. В., Благовещенский, С. Н., Холодилин, А. Н. (1969). Качка корабля. Ленинград: Судостроение. 


\title{
THE INFLUENCE OF STROKE RATE ON THE EFFICIENCY OF ROWING QUADRUPLE SCULLING BOATS
}

\author{
Algirdas Bingelis, Kazimieras Pukènas, Sigita Marija Zdanavičienė \\ Lithuanian Academy of Physical Education, Kaunas, Lithuania
}

\begin{abstract}
The study of academic quadruple sculling boats was associated with the previous studies by the authors on the mathematical modeling of the economy of single and double sculling boats influenced by vertical oscilation. There are no data in the scientific literature about the analysis of impact of free vertical oscilation which is achieved by vertical power impulses to the seat during each stroke. The decaying vertical oscillation influences the average growth of the draught, and thus the area of the wetted surface increases resulting in the growth of the boat draught when the stroke rate and the force of water resistance increase.

The aim of the study was to estimate the rowing efficiency indices of quadruple sculling boats $(4 \mathrm{x} /-)$ of different models (narrower - 8650, and wider - 8750) which were influenced by the factor of free vertical oscilation of the boat complex, and to establish the dependence of efficiency indices on certain parameters of the hull and the strength of rowers' vertical impact on the seat under the conditions of different rowing rate. The parameters of concrete academic boats necessary to estimate the rowing efficiency were established according to theoretical schemes. Applying the method of mathematical modeling we calculated the growth of the draught which was caused by the free vertical oscilation and established the change in the rowing efficiency depending on the rowing rate, the mass of the boat complex, and the amplitude of the vertical impact on the seat.

The analysis of the obtained results indicated that the coefficient of the vertical oscilation did not depend much on the mass of the boat complex. The water resistance force of the 8750 model boat, which is proportional to the magnitude of the wetted area and the wetted surface of which is greater compared to that of 8650 model, was less by $4.5 \%$. The highest positive value of the average growth of the draught (worst conditions) was greater for the 8650 model. With the increase of the rowing rate up to 44.5 and 47 strokes per minute for the 8750 and 8650 models respectively, the values of the growth of the draught equaled zero. When the rate continued to increase, the values of the growth of the draught became negative, and the draging conditions improved. The further increase in the rate was more effective for the 8650 model. The data about the average growth of the gauge during the drag (irrespective of the rate) preconditioned the more effective drag. Being aware of the change in the average growth of the draught we can choose the rate values when the average draught is lower. We suggest that free vertical oscilation impacts the change in the efficiency of rowing depending on the rate. It is expedient to evaluate the factors which impact the rowing technique of elite rowers.
\end{abstract}

Keywords: vertical oscilation, rowing efficiency, rate.

Gauta 2008 m. vasario $14 \mathrm{~d}$.

Received on February 14, 2008

Priimta 2008 m. gegužès 13 d.

Accepted on May 13, 2008
Algirdas Bingelis

Lietuvos kūno kultūros akademija

(Lithuanian Academy of Physical Education)

Sporto g. 6, LT-44221 Kaunas

Lietuva (Lithuania)

Tel +370 37302668

E-mail a.bingelis@1kka.lt. 